\title{
The Myth of Administrative Decentralization in the Context of Centralized Human Resources Recruitment in Tanzania
}

\author{
Mrutu Lukio Lawrence \\ School of Public Administration and Management, Mzumbe University \\ Tanzania \\ E-mail:1mrutu@mzumbe.ac.tz or mrutulukio@gmail.com \\ Stella Kinemo \\ School of Public Administration and Management, Mzumbe University \\ Tanzania \\ E-mail: smkinemo@mzumbe.ac.tz
}

Received: Oct. 21, 2018 Accepted: Feb. 20, 2019 Online published: Mar. 21, 2019

doi:10.5296/jpag.v9i1.13798～URL: https://doi.org/10.5296/jpag.v9i1.13798

\begin{abstract}
Tanzania is implementing the decentralization by devolution policy (D by D) as a mechanism of facilitating quick development process through the involvement of people from grass root levels. One of the areas for decentralization is administrative decentralization whereby local government authorities are regarded as autonomous organs when it comes to management of human resources from hiring to firing. However, recently from 2009, the government decided to establish a new centralized recruitment system, which recruits and allocates human resources on behalf of local government authorities and other government institutions. Several reasons have been advocated in favour of these changes like to facilitate uniformity and lack of meritocracy by the local government authorities. Using secondary data, this paper attempts to show how the establishment of centralized recruitment in Tanzania has acted as a thorn towards the full attainment of administrative decentralization. The paper ends by concluding that centralized recruitment has not only weakened local authorities in implementing D by D policy but it has left a lacuna in the real meaning of D by D policy.
\end{abstract}

Keywords: decentralization, administrative decentralization, centralized recruitment 


\section{Introduction}

From the early 1980s, decentralization has been one of the important policies adopted by many developing countries as a tool for political and economic advancement (Ribot, Agrawal, and Larson 2006). Decentralization has been adopted in many developing countries with the primary belief that it will facilitate quick development to all people at all levels. For example economists like Oates (1972) and Tiebout (1956), have advocated in favour of decentralization as it facilitates the provision of services and goods according to the preferences of local people which might be difficult to be attained through central government provision. Also decentralization has been advocated in facilitating the building of political stability when pressures arise among different groups of people at local levels (Jesse, 2002). It has also been advocated as a tool for bridging the gap between the government and people whereby with decentralized government, people become more involved in government activities through clearly defined structures and authority (Rohitarachoon and Hossain 2012). By definition, decentralization has been defined in different ways to the extent that there is no universal way of defining it. Decentralization is any act in which a central government formally cedes powers to actors and institutions at lower levels in a political-administrative and territorial hierarchy (Mawhood, 1983). Also Barnett et al., 1997 define decentralization as the transfer of authority, responsibility and accountability from the central government to local government.

Decentralization consists of three important dimensions, which are political, fiscal and administrative decentralization (Barnett et al. 1997). Political decentralization refers to a set of constitutional amendments and electoral reforms designed to open new or active existing, but dormant or ineffective-spaces for the representation of subnational politics (Falleti 2005). On the other hand, fiscal decentralization involves giving autonomy to local government authorities in collecting revenue and expenditure on the same (Awortwi 2010). Administrative decentralization involves the redistribution of authority, responsibility and financial resources for providing public services among different levels of government. It is the transfer of responsibility for the planning, financing and management of certain public functions from the central government and its agencies to field units of government agencies, subordinate units or levels of government, semi-autonomous public authorities or corporations, or area-wide, regional or functional authorities. Bringing services closer to people has been a primary motive towards decentralization in many countries. Many developing countries have adopted decentralization policy with the dream of fastening development process to all people (Green 2005). However, to what extent decentralization and all its forms and manifestations will be the key towards attainment of desired level of development has been a debate though countries like Uganda has been mentioned to have a well-functioning decentralized system (Braathen, Chaligha, and Fjeldstad n.d.)

Despite the fact there is little empirical evidence as to what extent decentralization policies have enabled developing countries to facilitate development to their people, Tanzania has been one of the countries which have deliberately embarked on this policy under a form of decentralization by devolution which was introduced in the local government reform programme in 1996. In this reform programme the government was aiming at enabling local 
government authorities to be autonomous, to have strong financial and human resources base, to operate in transparency and in an accountable manner and to be responsive in social services delivery (REPOA, 2010). Through the local government reform policy of 1998, it envisaged the key areas of decentralization, which are political decentralization, fiscal decentralization and administrative decentralization. With political decentralization, the reforms aimed at creating strong and well- functioning local authorities, which, through their local administrative structures will develop, implement and monitor the implementation of different activities to the people. In fiscal reforms, the motive has been to enable local authority financially so that they will not only depend on the central government but also be able to plan and spend on their own local sources. Moreover, in administrative reforms, the government aimed at allowing local authorities to make decisions with regard to hiring, firing, pay and oversee their own staff.

Though decentralization by devolution has been in its implementation for more than ten years now, the government of Tanzania, following some identified challenges on the existing recruitment process in local authorities, like nepotism, corruption and so on (see Njovu 2013), decided to re-establish a centralized recruitment system and hence removing the powers of local authorities to hire its own staffs. This paper attempts to show how the establishment of centralized recruitment of human resources in public service has affected the full attainment of administrative decentralization in the context of decentralization by devolution policy. The paper starts by reviewing theoretical aspects of administrative decentralization and then brings into light the issue of human resources recruitment in Tanzania and the question of administrative decentralization. Secondary data were used in this paper including journals, thesis and some Tanzanian government documents like Public Service Act (Amendment Act No. 18 of 2007), United Republic Of Tanzania (1998) 'Policy paper on local government reform, to reveal how centralized recruitment is acting as a step towards the end of decentralization by devolution in human resources. In more specific manner, this paper is guided by the following two objectives;

i. To examine recruitment practices in the Tanzanian Public Services before and after the introduction of centralized recruitment system.

ii. To show how the establishment of centralized recruitment is hampering the attainment of administrative decentralization.

\section{Literature Review}

In the last two decades developing world has experienced different kind of reforms aimed at increasing efficiency and effectiveness in service delivery. One of the reforms includes decentralization which gained its popularity in 1980s. Decentralization which refers to "the transfer of responsibility for planning, management and resource raising and allocation from the central government and its agencies to semi-autonomous local authorities, has been implemented in many developing countries as a mechanism of fastening grass root development (Ali Khan 2013; Khan 2013; Undp-government 1999). Scholars who support the policy of decentralization, believes that, with decentralization, local people are empowered to make decision which affect their own local development(Muriu 2014; 
Venugopal and Yilmaz 2010). The assumption lies in the fact that, local people know much about their localities in terms of challenges, opportunities and resources available, hence empowering them in planning, monitoring and managing their own development act as a catalyst towards local development.

Decentralization can take four different forms, namely delegation, devolution, deconcentration and privatization. Manor (1999) has categorized decentralization into three major types: deconcentration or administrative decentralization, fiscal decentralization, and devolution or democratic decentralization. Under administrative decentralization, local authorities are given power to deal with administrative responsibilities within their jurisdiction. On the other hand fiscal decentralization involves the transfer of authority to local authorities in raising, managing and allocation of financial resources. With democratic decentralization, local people are empowered to elect their own leaders (Awortwi 2010; Braathen, Chaligha, and Fjeldstad n.d.; Kauzya 2007; Muriu 2014; Mzee 2008).

\section{Administrative and Human Resources Decentralization}

One of the administrative functions for decentralization is human resources function. In this case local government authorities are the custodians of human resources activities like budget payroll, establishment control, recruitment, career management and performance management. It consists of three forms namely, deconcentration, delegation and devolution. These three different forms of administrative decentralization make it to be a spectrum whereby the movement along the spectrum depends on the nature of existing political and fiscal aspects of decentralization (Green 2005). Each of these forms defines the nature of autonomy, which is exercised whereby in the deconcentration central government has authority on local government staff by controlling everything. In delegation, though central government has authority on determining payments, local government is also having authority with regard to hiring and allocation of staff. In devolution, local authorities have the autonomy on the number of employees, salary, hiring, firing and their allocation but central government may remain to be the one, which establish standards and procedures of hiring and managing staff (Green, 2005). See the following framework, which illustrates the features of each form of administrative decentralization.

\begin{tabular}{|c|c|c|}
\hline Deconcentration & Delegation & Devolution \\
\hline $\begin{array}{l}\text { - Provider staff working } \\
\text { at local level are } \\
\text { employees of and } \\
\text { accountable to the } \\
\text { center, usually } \\
\text { through their }\end{array}$ & $\begin{array}{l}\text { - Providers could be } \\
\text { employees of central } \\
\text { or local government, } \\
\text { but the centre } \\
\text { typically defines pay } \\
\text { and employment }\end{array}$ & $\begin{array}{l}\text { Providers are } \\
\text { employees of local } \\
\text { government. Local } \\
\text { government has full } \\
\text { discretion over salary } \\
\text { levels, allocation, and }\end{array}$ \\
\hline
\end{tabular}




\begin{tabular}{|c|c|c|}
\hline $\begin{array}{l}\text { respective ministries; } \\
\text { central employees } \\
\text { compensate for weak } \\
\text { local capacity } \\
\text { - Accountability } \\
\text { remains distant: the } \\
\text { short route of } \\
\text { accountability may be } \\
\text { weak if provider } \\
\text { monitoring is weak, } \\
\text { and citizens may have } \\
\text { to rely on a weak long } \\
\text { route stretching to } \\
\text { politicians at the } \\
\text { centre; a strong } \\
\text { compact between } \\
\text { policymakers and } \\
\text { providers can } \\
\text { compensate to some } \\
\text { extent. }\end{array}$ & $\begin{array}{l}\text { - Local government } \\
\text { has some authority } \\
\text { over hiring and } \\
\text { location of staff, but } \\
\text { is less likely to have } \\
\text { authority over firing } \\
\text { Both long and short } \\
\text { routes of } \\
\text { accountability are } \\
\text { potentially stronger; } \\
\text { greater local } \\
\text { knowledge can allow } \\
\text { better matching of } \\
\text { supply with local } \\
\text { preferences and better } \\
\text { monitoring, } \\
\text { strengthening both } \\
\text { the compact and } \\
\text { client power. }\end{array}$ & $\begin{array}{l}\text { numbers of staff, as } \\
\text { well as the authority } \\
\text { to hire and fire } \\
\text { - An overarching civil } \\
\text { service framework } \\
\text { covering local } \\
\text { governments may still } \\
\text { establish standards } \\
\text { and procedures for } \\
\text { hiring and managing } \\
\text { staff } \\
\text { Potentially strongest } \\
\text { long and short routes } \\
\text { to accountability, but } \\
\text { influenced by local } \\
\text { social norms and } \\
\text { vulnerable to local } \\
\text { capacity constraints } \\
\text { and politics }\end{array}$ \\
\hline
\end{tabular}

Source: Adapted from World Bank 2003h, 189 cited in Green 2005 Pg. 130

Decentralized human resources have been advocated as a tool to facilitate effective and efficient management of human resources whereby local governments are given discretion to take care of all issues of human resources within their jurisdiction (Coggburn 2005). It is also argued that the decentralized human resources function facilitates flexibility, innovation, responsiveness and better decision-making (Hays and Kearney 2001). Again, there is argument that the decentralization of human resources function matches with the needs of new public management, which emphasize on the management for results, performance management, corporate planning and devolution of authority and decentralization of authority. (Brown, 2004 in Njovu, 2013) 


\section{Human Resources Recruitment in Tanzania}

\section{From 1961 to 2008}

The history of recruitment of civil servants in Tanzania can be traced since the attainment of its independence in 1961 when there was no clear and well defined policy to guide the process (Shangali, 2009). According to Shangali, during this period vacant posts were filled under the guide of General orders, Administrative Circulars and Staff Circulars. Graduates and secondary school leavers were recruited by direct employment through Manpower Allocation Committee of the Central Establishment. Later, the appointment of graduates up to middle level employees delegated to Civil Service Commission, Local Government Service Commission and Teachers Service Commission. Each Commission was left to lay down its own modalities, standards and procedures for filling vacant posts. Also Common cadres (operational service) were recruited by applying direct to the employers and which then were to be approved by Appointment Committee and internal recruitment was done through promotion and transfers. However, because these differences Public servants did not receive unequal treatments on matters of appointment and promotions and recruitment was not based on meritocracy (Shangali, 2009).

In 1972 local government authorities were abolished and therefore all issues with regard to human resources were centrally performed under Civil Service Department (Munga et al. 2009). However, following the re-establishment of Local government authorities in 1982, all issues of human resources like recruitment, promotion, transfer, discipline were vested in the authority of Local Government Service Commission. (REPOA, 2008, cited by Njovu, 2013). Later in 1998, following the adoption of decentralization by devolution policy which was followed by the Local government Reform Programme, local authorities were given full discretion with regard to human resources from planning, recruiting, rewarding and development (URT, 1998). This was followed by the Local government service regulation of 2000 which also devolved the issues of recruitment, appointment and management of staff to local councils except for council directors who were left under the authority of central government. Though the power to hire and firing were left in the hands of local authorities, still there were some central control through the Prime Minister's Office-Public Services Management on the issues of salaries, staff budget and number, pay scale and policies and transfers (Tidemand and Msami, 2010 cited by Njovu, 2013).

\section{From 2009 to Date}

From 2009, following the establishment of Public Service Recruitment Secretariat under the Public Service (Amendment) Act 2007, all the powers to recruit human resources were vested to this secretariat. The established Public Service Recruitment Secretariat (PSRS) is responsible for conducting recruitment of public servants in Public service (Kinemo et al; 2015). The roles of the local authorities remains of identifying the vacant posts and send their request to President Office-Public Service Management (PO-PSM) whereby the Secretariat will then conduct all process of recruitment and allocate the staffs according to the needs of each local authority (URT, 2007). However, recently, the process of recruitment for some position in Local government authorities which were done by the secretariat like the position 
for Village Executive Officer, Ward Executive officers, Drivers and Secretaries. Among the reasons for the shift from decentralized to centralized recruitment process as was presented by (Njovu, 2013) following his study in Morogoro on the centralized and decentralized recruitment in local authorities includes lack of meritocracy, unethical conducts by the local authorities during recruitment, to facilitate equal distribution of human resources and lack of expertise in local authorities who will manage properly recruitment process. Though the centralized system has got several positive effects like the decrease of corruption, nepotism and allocation of qualified staffs, still complains have been waged against the system like delays in feeling vacant posts, increase in forgery among allocated employees, the increase of labour turn over due to the fact that some are allocated in the areas which are not of their choices compared to the time when local authorities were recruiting themselves as one knows from the first point as where he will be working (Njovu, 2013,Mrutu and Ngowi, 2016).

\section{Discussion}

The well-intended reforms of devolving the powers to local authorities on the issues of human resources started to be spoiled even during the early phases of decentralization by devolution. For example the Public Service Act of 2002 gave powers to President's Office Public Service Management to deal with issues of human resources instead the prime minister's office-regional administration and Local Government. Another setback which emerged was in 2003 when the public service regulations kept the powers of central government in dealing will all issues of transfer of staff across local authorities and regions whenever deemed necessary under the basis of public interest (REPOA, 2010). One of the key areas of LGRP is to have autonomous local authorities through devolution of authorities in political, legal, administrative and changed relations between Central-Local relations (REPOA, 2010). In administrative devolution the centralized human resources system was to be replaced by the highly decentralized one whereby local authorities are empowered to deal with all matters relating to human resources from planning, hiring, pay, firing and discipline (Munga et al; 2009). With these changes to the centralized system though it was aimed at efficiency in human resources recruitment and allocation, still some questions have to be considered under the image of the so called decentralization by devolution. Do these changes reveal some weakness on the whole decentralization process, as maybe it was poorly planned or was adopted without enough capacity at local authorities? Because even before the changes to centralized system still local authorities were operating in the realm of "Responsibility without Authority" as it was unveiled by Munga et al; 2009. According to Munga et al; (2009), decentralization in Tanzania took place in the midst of the weak local institutions, most of which fell under the hands of selfish politicians who are given so much power by the laws in the administration of local councils and therefore sometimes used threats to influence recruitment process. Braathen et al; (2005) argued that though decentralization by devolution in Tanzania is on track, but it is still behind when compared to some countries like Uganda in the areas of Human resources and fiscal decentralization due to several government initiatives which do not give room for true autonomy in local authorities.

The major question to ask is what are these changes geared to? The central motive of the 
decentralization policy as was described by Ngwilizi (2013) is to have independent local authorities which will play a great role towards sustainable development. Basically, with this move even the little autonomy of the local authorities with regard to recruitment has been taken away which in one way or another it might be seen as sliding back to what was practised during the early phase of decentralization by decocentration in 1972. The importance of having independent local authorities is presented by Munga et al (2009) as a strategy of solving the ever growing increase of shortage of human resources for health in many districts in Tanzania. According to him, local government autonomy financially and in human resources administration will solve the problems of recruiting health workers in remote districts through the use of local budget to motivate its employees to work in areas which most people do not want to go for the truth that the areas are remote and no motivation is given.

\section{Conclusion}

This paper intended to show how the establishment of centralized recruitment is impeding the attainment of administrative decentralization. Though the evidence from past studies revealed weakness in the decentralized system of local authorities, the solution could not be to remove recruiting powers from local authorities rather a comprehensive capacity building would have been made in local authorities on the areas of human resources administration. This will ensure that the dream towards autonomous local authorities will be realized. Again, the reason that local government authority's recruitment process was filled with some kind of manipulation and threats from local councilors could have been solved by formulating the employment committees which are independent from political influences. As a result of these changes there has been some complains caused by the delays in filling of identified vacant. It is evident that the establishment of centralized recruitment acts as a challenge in attaining the intended decentralization in managing human resources. One of the emerging implications of these changes is the creation of some bottleneck in making decisions with regard to human resources welfare. This might be a new study area to see to what extent these changes have affected local government authorities in making decisions which affect the welfare of the employees.

\section{Reference}

Ali Khan, S. (2013). Decentralization and poverty reduction: A theoretical framework for exploring the linkages. International Review of Public Administration, 18(2), 145-172. https://doi.org/10.1080/12294659.2013.10805256

Awortwi, N. (2013). The past, present, and future of decentralisation in Africa: a comparative case study of local government development trajectories of Ghana and Uganda. In Public Sector Reform in Developing and Transitional Countries (pp. 46-60). Routledge.

Barnett, C. C., Henry, P. M., \& Jerry, V. (1997). Democratic Decentralization. (December): $0-19$. 
Braathen, E., Chaligha, A., \& Fjeldstad, O. H. (2004). Local governance, finances and service delivery in Tanzania. In Workshop, which took place in Dar es Salaam in March (Vol. 25, p. 26).

Coggburn, J. D. (2005). The benefits of human resource centralization: Insights from a survey of human resource directors in a decentralized state. Public Administration Review, 65(4), 424-435. https://doi.org/10.1111/j.1540-6210.2005.00469.x

Falleti, T. G. (2005). A sequential theory of decentralization: Latin American cases in comparative perspective. American Political Science Review, 99(3), 327-346. https://doi.org/10.1017/S0003055405051695

Green, A. (2005). Managing Human Resources in a Decentralized Context. East Asia decentralizes: Making local government ...: 129-54. http://books.google.com/books?hl=en\&lr=\&id=_XO6xllwH14C\&oi=fnd\&pg=PA129\&dq=M anaging+Human+resources+in+a+decentralized+Context\&ots=DWsF6JmPam\&sig=osQxtw QuRICP76HRLOuA7MU4V5c.

Hays, S. W., \& Kearney, R. C. (2001). Anticipated changes in human resource management: Views from the field. Public Administration Review, 61(5), 585-597. https://doi.org/10.1111/0033-3352.00129

Kauzya, J. M. (2007). Political Decentralization in Africa: Experiences of Uganda, Rwanda and South Africa. Decentralizing governance: Emerging concepts and practices, 75-91.

Manor, J. (1999). The Political Economy of Democratic Decentralization (The World Bank, Washington, DC).

Mrutu, L. L., \& Ngowi, A. O. (2016). How centralized recruitment influence employee's turnover in Tanzania Local Government Authorities: Experience from Moshi Municipal Council. International Journal of Academic Research in Business and Social Sciences, 6(9), 2222-6990. https://doi.org/10.6007/IJARBSS/v6-i9/2314

Munga, M. A., Songstad, N. G., Blystad, A., \& Mæstad, O. (2009). The decentralisation-centralisation dilemma: recruitment and distribution of health workers in remote districts of Tanzania. BMC international health and human rights, 9(1), 9. https://doi.org/10.1186/1472-698X-9-9

Muriu, A. R. (2014). 1 How does Citizen Participation impact Decentralized Service Delivery? Lessons from the Kenya Local Authority Service Delivery Action Plan (LASDAP, 2002-2010) i.

Mzee, M. M. (2008). Local Government in Tanzania: Does the Local Government Law in Tanzania Give Autonomy To Local Government. (November). http://etd.uwc.ac.za/usrfiles/modules/etd/docs/etd_gen8Srv25Nme4_5923_1306481925.pdf.

Ribot, J. C., Agrawal, A., \& Larson, A. M. (2006). Recentralizing while decentralizing: how national governments reappropriate forest resources. World development, 34(11), 1864-1886. https://doi.org/10.1016/j.worlddev.2005.11.020 


\section{Macrothink}

Journal of Public Administration and Governance ISSN 2161-7104 2019, Vol. 9, No. 1

Rohitarachoon, P., \& Hossain, F. (2012). Decentralized Recruitment and Selection in Thailand: Friend or Foe to Local Public Administration?. International Journal of Public Administration, 35(8), 553-561. https://doi.org/10.1080/01900692.2011.653513

Undp-government, Joint. (1999). Decentralization: A Sampling of Definitions. (October).

Venugopal, V., \& Yilmaz, S. (2010). Decentralization in Tanzania: an assessment of local government discretion and accountability. Public Administration and Development, 30(3), 215-231. https://doi.org/10.1002/pad.556

\section{Copyright Disclaimer}

Copyright for this article is retained by the author(s), with first publication rights granted to the journal.

This is an open-access article distributed under the terms and conditions of the Creative Commons Attribution license (http://creativecommons.org/licenses/by/4.0/). 